\title{
First Report of Leaf Spot Disease on Yucca Plant Caused by Alternaria alternata from India
}

\author{
Manjul Pandey* \\ KVK, Banda, Banda University of Agriculture and Technology, Banda-210001(India) \\ *Corresponding author
}

Keywords

Leaf spot, Foliar disease, Yucca plant, Alternaria alternata

Article Info

Accepted:

17 December 2018

Available Online:

10 January 2019

\section{A B S T R A C T}

A leaf spot disease of Yucca plants is prevalent in India. They are native to the hot and dry parts of America and the Caribbean. Yucca is similar to agave but often forms trunks and typically has more numerous, thinner, leathery leaves with a smaller terminal spine. Yucca leaves range in color from deep green to pale blue, and leaves may be striped in shades of white, cream, yellow, or chartreuse. They are also used in pharmaceutical industries for medicinal properties When in flower yucca produces large, upright panicles (flower clusters) of white, bell-shaped flowers. Symptomatic can be seen on the upper and lower side of leaves like to be small and circular spots with concentric rings at first which later became irregular lesions. These circular spots were dark black coloured with necrotic region. Purified fungal suspension $\left(1 \times 10^{5} \mathrm{cfu} / \mathrm{ml}\right)$ was sprayed on healthy plants for the confirmation of pathogencity test. Koch's Postulates were established. This fungus was identified as Alternaria alternata and is the first report of 'leaf spot disease' on this host from India.
Yucca is a genus of perennial shrubs and trees in the family Asparagaceae subfamily Agavoide. Its 40-50 species are notable for their rosette of evergreen through, sword shaped leaves and large terminal panicles of white or whitish flowers. They are native to the hot and dry parts of America and the Caribbean. Yucca is similar to agave but often forms trunks and typically has more numerous, thinner, leathery leaves with a smaller terminal spine. Yucca leaves range in color from deep green to pale blue, and leaves may be striped in shades of white, cream, yellow, or chartreuse. When in flower yucca produces large, upright panicles (flower clusters) of white, bell-shaped flowers. Unlike the tall lower stems of agave, panicles of Yucca plant are held within or just above the foliage (Knox, 2010; Kelly and Olsen, 2008) and they are also used in pharmaceutical industries for medicinal properties.

Yucca plants were grown in Horticulture Garden, C.S. Azad University of Agriculture and Technology, Kanpur for production of ornamental nursery for beautification purpose. In the continuation of disease observation during 2007-2008, the garden plant (Yucca spp.) leaves were showing leaf spot symptom on aerial parts of plants. Symptoms appeared 
to be small and circular spots with concentric rings at first which later became irregular lesions on upper and lower side of leaves. These circular spots were dark black coloured encircled the necrotic region. With the spread of disease, these necrotic spots turned to appear as blight. They coalesce on severely infected leaves which eventually die and generally more severe infection on lower portion of plants (Fig.1, 2(A,B) \& 3). The samples were placed in separate polyethylene bags and transported to the laboratory and processed as per the standard techniques given by Hawskworth (1974). The infected leaves and flowers should be disinfected /surface sterilized in $10 \%$ Clorex $(0.5 \%)$ solution for 2 minutes. Thereafter, wash the material thoroughly using sterilized distilled water. Then small leaf bits from margin of newly emerged spot were cut with the help of a sterilized scalper. The leaf bits were dipped in $0.1 \% \mathrm{Hgcl}_{2}$ solution for 30 seconds with the help of sterilized forceps and washed thoroughly 4-5 times with sterilized water to remove the traces of $\mathrm{Hgcl}_{2}$.

Fig.1,2,3\&4 Healthy plant of Yucca spp.

Fig-2(A,B): Infected plant of Yucca spp.(A) Symptom on upper side (B) Symptom on lower side Fig-3: Healthy leaf and infected leaves shows symptoms on upper and lower side.

Fig-4: Mycelium and conidia of Alternaria alternata fungus

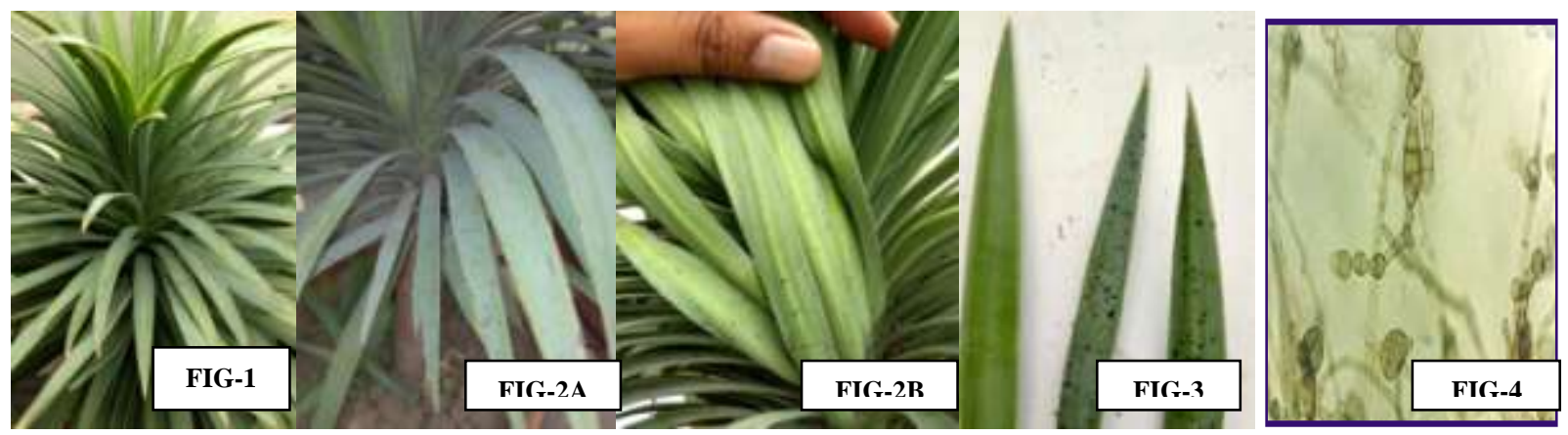

The pieces were transferred with the help of sterilized forceps into Petri dishes already poured with sterilized $2 \%$ potato dextrose agar (PDA) medium and were kept in B.O.D. chamber at $25^{0}+1^{0} \mathrm{C}$ for incubation of the pathogen. The myclial growth was viable around the pieces; hyphal tips from the advancing mycelium were transferred aseptically into the sterilized culture tubes containing 2\% PDA medium. The culture was purified by single spore technique method (Vishunavat and Kotle, 2008). The pure culture of the fungal colony appeared to be grayish white at first and became balck later on. The fungus produced abundant, conidia having mycelium was septate, branched, dark olive buff, measuring $3.1-5.2 \mu \mathrm{m}$ in diameter; conidiophores septate, simply sometimes branched, erect, geniculate, dark olive buff, measured 23.8-78.5 x 3.4-6.3 $\mu$ m;Conidia muriform, ovoid to obclavate, arranged in long branched chains, dark olive buff, smooth, sometimes verruculose, measured 15.5-43.3 x 8.6-14.1 $\mu \mathrm{m}$ with 1-5 transverse and 0-4 longitudinal septa; beak usually light in colour, measured $3.2-18.7 \times 3.1-5.3 \mu \mathrm{m}$ with 0-2 cross septa. The morphological characters of the pathogen observed are more or less, same as described by Keissler (1912), Simmons (1967) and Ellis (1971) for various isolates of Alternaria alternata (Fr.) and was identified as such. (Fig.4). For confirmation of the pathogenicity test, it was a homogenous suspension was prepared from one week's old 
culture in sterilized water. The suspension containing conidia and mycelia bits was churned in warring blender and strained with muslin cloth. The suspension containing approximately $1 \times 10^{5} \mathrm{cfu} / \mathrm{ml}$ was sprayed on 3 month old healthy plants with the help of automizer and sterile water was used as a control. Treated plants were covered for $24 \mathrm{~h}$ with plastic bags to maintain $100 \%$ relative humidity and kept under observation for 10 days in the laboratory garden at $30+5^{\circ} \mathrm{C}$. The pathogenicity test were repeated three times. The characteristic lesions developed within 7 days of inoculation and Koch's postulates were fully established. On the basis of pathogenicity, morphological and cultural characteristics of fungus was identified Alternaria alternate (Fr.) Keissler. The fungus was also confirmed by Indian Type Culture Collection, Department of Mycology and Plant Pathology, Indian Agricultural Research Institute, New Delhi, India and they provide to me an accession number (ITCC 6421).

A survey of the literature reports the occurrence of only a few fungal diseases on Yucca spp. Leaf Tip die back disease of Yucca elephantipes by Lasidioplodia theobromae in Nigeria reported by Aigbokhan et al., (2007). Pscheidt and Ocamb (2018) reported leaf spot of disease of Yucca plant caused by Coniothyrium bartholomaei in Oregan(USA). Saha (1995) also reported leaf spot of diseases of Yucca caused by Coniothecium concentricum in India. Therefore, to the best of our knowledge, the leaf spot disease on Yucca plant caused by Alternaria alternata is the first report from Uttar Predesh (India).

\section{References}

Aigbokhan, O.F.; Claudius-cole, A.O. and Ikotun,B. (2017). Leaf Tip die-back of Yucca elephantipes by Lasidioplodia theobromae Pat. and Production of Phytotoxin in Filtrate and infected leaves. Journal of Experimental Agric. International. 16(3):1-8.

Ellis, M.B., (1971). Dematiaceous Hyphomycetes, C.M.I., Kew, England, p.608

Hawskworth, D.L. (1974). Mycologist's Handbook. CMI, Kew. Pp. 231.

Keissler, K.V. (1912). Zur Kenntnis der pilzflora Krains. Beith. Bot. Centre, 29: 395-440.

Psacheit, J.W. and Ocamb, C.M. (2018). Pacific North west Plant disease Management Handbook. Oregon State University, USA. pp. 1-2.

Saha, L.R. (1995). Handbook of Plant Protection. Kalyani Publication, India. pp. 796-797.

Simmons, E.G. (1967). Typification of Alternaria, Stemphylium and Ulocladium. Mycologia, 59: 67-92.

Vishunavat, K and Kotle, S.J. (2008). Essentials of Phytopathogical Techniques. ( $2^{\text {nd }}$ Eds.). Kalyani Publishers, New Delhi. pp. 54-96.

\section{How to cite this article:}

Manjul Pandey. 2019. First Report of Leaf Spot Disease on Yucca Plant Caused by Alternaria alternata from India. Int.J.Curr.Microbiol.App.Sci. 8(01): 2876-2878.

doi: https://doi.org/10.20546/ijcmas.2019.801.303 